\title{
Equipped for Life in the Boreal Forest: The Role of the Stress Axis in Mammals RUDY BOONSTRA, ${ }^{1,2}$ BEN DANTZER, ${ }^{3}$ BRENDAN DELEHANTY, ${ }^{1}$ QUINN E. FLETCHER ${ }^{4}$ and MICHAEL J. SHERIFF ${ }^{5}$
}

\author{
(Received 19 February 2012; accepted in revised form 20 July 2012; published online 21 February 2014)
}

\begin{abstract}
The hypothalamic-pituitary-adrenal axis (stress axis) plays a central role in equipping mammals to succeed in the challenging environment of the boreal forest. Over the last 20 years, we have tackled a broad range of topics to understand how the stress axis functions in four key herbivore species. The central challenge for snowshoe hares is coping with their predators, whereas for the others, it is primarily coping with each other (especially during reproduction) and with their physical environment. Hares are severely stressed by their predators during the population decline. The predator threat causes major changes in the stress axis of hares and reduces their reproduction; in addition, acting through maternal programming, it is the most plausible explanation for the extended period of low numbers following the population decline. Arctic ground squirrel males have an intense breeding season for two to three weeks in early spring, after which many of them die. The functioning of their stress axis changes markedly and is key in meeting their energy demands during this period. In contrast, red-backed vole males, though also short-lived, breed repeatedly only in the summer of their life, and their stress axis shows no change in function. However, their reproductive effort negatively affects their long-term survival. Territorial red squirrels experience marked interannual fluctuations in their major food source (white spruce seed), resulting in major fluctuations in their densities and consequently in the intensity of territorial competition. Changes in the densities of red squirrels also alter maternal stress hormone levels, inducing adaptive plasticity in offspring postnatal growth rates that prepares offspring for the environment they will encounter at independence. To survive winter, red squirrels need to defend their territories year-round, and the basis of this defense appears to be adrenal dehydroepiandrosterone, which has the benefits, but not the costs, of gonadal steroids. Arctic ground squirrels survive winter by hibernating in deeply frozen ground. Unlike all other hibernators, they have evolved a unique adaptation: high levels of adrenal androgens in summer to accumulate protein reserves that they then burn in winter. With a rapidly changing climate, the stress axis will play a key role in permitting northern animals to adapt, but the linkages between the changes in the abiotic and biotic components of the boreal forest and the phenotypic plasticity in the stress response of its inhabitants are not well understood for these or any other herbivore species.
\end{abstract}

Key words: stress axis, maternal programming, predation risk, hibernation, life history, longevity, territoriality, DHEA, adrenal androgens, snowshoe hare cycle

RÉSUMÉ. L'axe hypothalamo-hypophyso-surrénalien (l'axe du stress) joue un rôle central pour aider les mammifères à réussir dans l'environnement difficile de la forêt boréale. Ces 20 dernières années, nous nous sommes penchés sur une vaste gamme de sujets afin de comprendre comment fonctionne l'axe du stress chez quatre grandes espèces herbivores. Pour le lièvre d'Amérique, le défi central consiste à faire face à ses prédateurs, tandis que pour les autres espèces, ce défi consiste à se faire face mutuellement (surtout pendant la reproduction) de même qu'à faire face à leur environnement physique. Les lièvres subissent beaucoup de stress de la part de leurs prédateurs pendant la diminution de la population. La menace des prédateurs est la cause de changements majeurs sur l'axe du stress des lièvres, ce qui a pour effet de réduire leur reproduction. De plus, en raison de leur programmation maternelle, il s'agit de l'explication la plus plausible justifiant la période prolongée de leur faible nombre suivant la diminution de la population. Le spermophile arctique mâle a une période de reproduction intense pendant deux à trois semaines au début du printemps et après cela, un grand nombre d'entre eux meurent. Le fonctionnement de son axe de stress change de façon marquée, ce qui est essentiel à sa demande en énergie pendant cette période. Par contraste, le campagnol à dos roux mâle, même s'il ne vit également pas longtemps, se reproduit à répétition seulement pendant l'été de sa vie, et le fonctionnement de son axe de stress ne montre aucun changement. Cependant, ses efforts de reproduction ont des incidences négatives sur sa survie à long terme. Pour sa part, la principale source d'alimentation (les graines d'épinette blanche) de l'écureuil roux territorial connaît des fluctuations interannuelles marquées, ce qui se traduit par une fluctuation

\footnotetext{
${ }^{1}$ Centre for the Neurobiology of Stress, Department of Biological Sciences, University of Toronto Scarborough, Toronto, Ontario M1C 1A4, Canada

${ }^{2}$ Corresponding author: boonstra@utsc.utoronto.ca

${ }^{3}$ Department of Zoology, University of Cambridge, Cambridge, United Kingdom CB2 3EJ

${ }^{4}$ Département de biologie, chimie et géographie, Université du Québec à Rimouski, 300 allée des Ursulines, Rimouski, Québec G5L 3A1, Canada

${ }^{5}$ Department of Ecosystem Science and Management, Pennsylvania State University, University Park, Pennsylvania 16801, USA

(C) The Arctic Institute of North America
} 
majeure en matière de densité de cette espèce animale et, par conséquent, en matière d'intensité de la concurrence pour le territoire. Les changements de densité d'écureuils roux exercent également une influence sur les taux d'hormone maternelle de stress, ce qui donne lieu à une plasticité adaptative des taux de croissance postnatale de la progéniture qui prépare la progéniture pour faire face à l'environnement dans lequel ils évolueront au stade de l'indépendance. Pour survivre à l'hiver, l'écureuil roux doit défendre son territoire à l'année et pour y parvenir, il se sert de la déhydroépiandrostérone surrénalienne, qui comporte les avantages des stéroïdes gonades, sans les coûts. Le spermophile arctique survit à l'hiver en hibernant dans le sol gelé en profondeur. Contrairement à tous les autres hibernateurs, il s'est développé une adaptation unique en son genre, soit des taux élevés d'androgènes surrénaliens en été qui lui permettent d'accumuler les réserves de protéines qu'il brûle ensuite pendant l'hiver. À la lumière du changement climatique rapide, l'axe de stress jouera un rôle-clé pour permettre aux animaux du Nord de s'adapter, mais les liens entre les changements des composantes abiotiques et biotiques de la forêt boréale et la plasticité phénotypique de la réaction de stress de ses habitants ne sont pas bien compris dans le cas de ces espèces herbivores ou de toute autre espèce herbivore.

Mots clés : axe du stress, programmation maternelle, risque de prédation, hibernation, cycle biologique, longévité, territorialité, DHEA, androgène surrénalien, cycle du lièvre d'Amérique

Traduit pour la revue Arctic parc Nicole Giguère.

\section{INTRODUCTION}

The adaptations of organisms in the natural world are solutions to ecological problems: the abiotic environment, scramble competition for resources such as food, the social environment (intra- and interspecific contest competition), and natural predators. These problems are the agents of selection, and their solutions result from the differential fitness among phenotypes (MacColl, 2011). The boreal forest presents a unique blend of ecological problems for organisms that live there. Its relatively simple, but harsh ecosystem is characterized by marked seasonality, with a burst of primary productivity during short, cool summers and permanent snow cover through the long, cold winters. Homeotherms in this forest require adaptations to cope with the many challenges that they face. These include severe and often unpredictable weather, with reproduction compressed into a very limited summer window; food resources that are highly variable from one year to the next (e.g., the mast years of red squirrels; Boutin et al., 2006); and marked variation in predator numbers associated with the 10-year snowshoe hare cycle (Krebs et al., 1995, 2014). These variables can influence population densities from one year to the next and hence there can also be fluctuations in intraand interspecific competition for space and resources. Most bird species avoid some of these problems by migration (e.g., McKinnon et al., 2010), but mammals are year-around residents. We focus on the stress axis (the hypothalamicpituitary-adrenal axis, or HPA axis) as one of the key physiological systems that mediate the relationship of the organism with its environment, in terms of both short-term responses and long-term evolutionary responses to particular ecological and environmental challenges. Others have examined how birds cope with the challenges of existence at high latitudes (reviewed by Wingfield et al., 2011). We urge the reader to consult these studies to complement our studies on mammals.
The stress axis is a critical neuroendocrine pathway that integrates these environmental challenges while at the same time playing a key role in life history decisions to reproduce, to grow, and to allocate energy into storage (McEwen, 2001; Wingfield and Romero, 2001; Ricklefs and Wikelski, 2002). In southwestern Yukon, we have tackled a broad range of topics over the last 20 years to understand how the stress axis functions to permit survival and reproductive success in four key herbivores: snowshoe hares (Lepus americanus), Arctic ground squirrels (Urocitellus parryi), North American red squirrels (Tamiasciurus hudsonicus), and red-backed voles (Myodes rutilus).

The topic of stress physiology is enormous and complex, ranging from the cellular and molecular to the whole animal. The HPA axis is a vital regulator of adaptation. The glucocorticoid hormones from the adrenals are known to influence the expression of approximately $10 \%$ of the genome, and their targets include genes controlling metabolism, growth, repair, reproduction, and the management of resource allocation (Le et al., 2005). We will give only the broad-brush overview here and a short primer below (for more comprehensive reviews see Sapolsky et al., 2000; Wingfield and Romero, 2001). The term "stress" tends to be a vague, inclusive one, but here we use it informally as the general physiological response to stressors (e.g., severe weather event, lack of sufficient food, attack by a conspecific or predator, fear). The set of responses by the stress axis enables animals to deal with a stressor and then returns them to a homeostatic state. All the adaptations we discuss below are physiological solutions by the stress axis to ecological problems with which these herbivores have a long evolutionary history. In addition, we discuss evolutionary modifications of the adrenals, a component of this axis, that permit some species to cope with winter. Recently climate change has emerged as a new challenge that is acting rapidly and with pronounced impact. The success or failure of these species to meet this challenge may partly depend on the functioning of the stress axis. 


\section{A Primer on the Stress Response}

Stressors (predator attack, social interaction, etc.) activate a rapid cascade of responses that permit the animal to deal with the stressor and then to re-establish homeostasis. Homeostasis is the attempt by the body to maintain stability in body processes in the face of environmental change. Within seconds, the sympathetic nervous system causes the adrenal medulla to release catecholamines (epinephrine and norepinephrine) into the general circulation (the classic "fight or flight" responses). We do not deal with these changes here as they are too rapid for study in wild mammals. Within three minutes, a second cascade of hormones is released, first from the hypothalamus (primarily corticotropin-releasing hormone, or $\mathrm{CRH}$ ), then from the pituitary (adrenocorticotropic hormone, or ACTH), and finally from the adrenal cortex (glucocorticoids, or GCs: either cortisol, or corticosterone, or both, depending on the species) (Fig. 1). The GCs signal the body to mobilize energy, suppress physiological processes not required to deal with the stressor, and return the body to homeostasis after the stressor has passed. Under conditions when the stressor is acute, termination of the stress response is accomplished by GCs exerting negative feedback (primarily to the pituitary) to return the body to its pre-activation state. Crucial to this feedback are the intracellular GC receptors (mineralocorticoid receptors, or MR, and glucocorticoid receptors, or GR). In addition, the primary GC plasma carrier protein, corticosteroid-binding globulin (CBG), plays a major role in modulating the impact of the stress response. CBG binds GCs in blood, as only free GCs appear to enter cells and have biological effects; lower CBG concentrations mean more GCs are free (Breuner et al., 2013). CBG levels can vary during reproduction, are reduced under chronic stress, and vary among species for reasons that are unclear (e.g., from our Yukon work see Boonstra et al., 1998; Boonstra and McColl, 2000; Delehanty and Boonstra, 2011; note that numerous other studies in both the laboratory and field have made similar findings [reviewed in Desantis et al., 2013]).

To assess the responsiveness of the stress axis, we quantified blood-based measures of stress axis response, including total and free GCs (not bound to $\mathrm{CBG}$ ), CBG levels, energy mobilization (glucose and free fatty acids), indices of immune functioning, and indices of condition. Because we rely on capturing mammals in live traps, levels in our initial blood sample - called our baseline - are already affected by capture and handling, and thus are not true baseline levels reflecting resting levels. Nevertheless, since our trapping and handling methods are consistent over time, any marked differences between samples indicate real differences in the animals themselves that result from changes in predator abundance, food supply, animal age, or season. In some studies, we have measured fecal corticosteroid metabolite (FCM) levels rather than blood GC levels. FCMs represent an integrated average of free GCs found in plasma that the animal has secreted, metabolized, and excreted over the course of a species-specific amount of

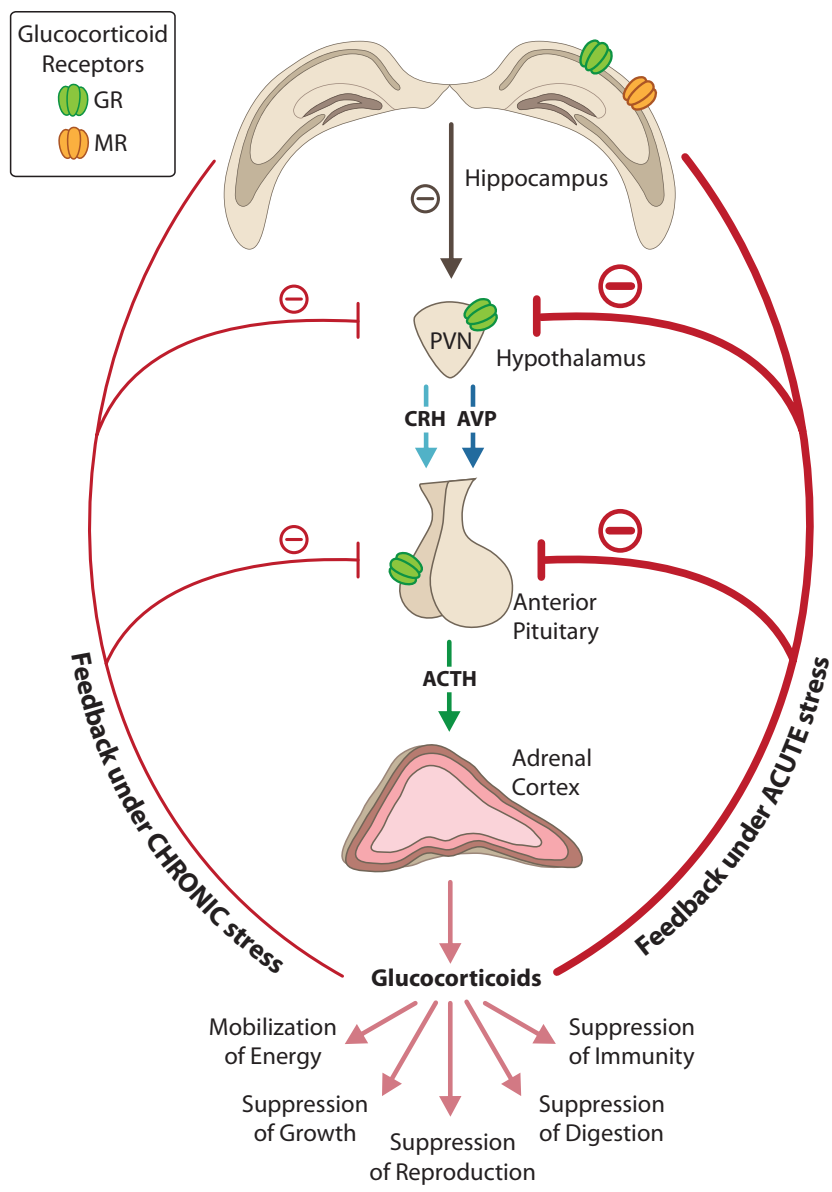

FIG. 1. The hippocampus and the hypothalamic-pituitary-adrenal (HPA) axis, the major impacts on body processes, and the glucocorticoid (GC) negative feedback in the mammalian brain. A stressor causes the hypothalamic paraventricular nucleus (PVN) to release corticotropin-releasing hormone (CRH) and arginine vasopressin (AVP), which cause the anterior pituitary to release adrenocorticotropic hormone $(\mathrm{ACTH})$. ACTH stimulates the adrenal cortex to synthesize and release glucocorticoids (GCs) into circulation. GCs act at multiple sites within the body to maintain homeostasis, but because of the negative effects of extended exposure to GCs, the HPA axis is tightly regulated through feedback on glucocorticoid receptors (GR) and mineralocorticoid receptors (MR) to inhibit further HPA activity. Inhibition is indicated by a minus sign (-). Cortisol feeds back on the PVN and pituitary to cause a rapid inhibition of $\mathrm{CRH}$ release. Under conditions where the stressor is acute, feedback mechanisms operate efficiently and the system rapidly returns to normal. Under conditions where the stressor is chronic, feedback signals are weak, and the system remains activated for longer periods (adapted from Boonstra et al., 2004).

time (Sheriff et al., 2011a). Unlike plasma samples, FCMs are not affected by capture and handling stress as long as the time from the initial $\mathrm{GC}$ release into blood owing to the stress of capture to its appearance as FCMs in the feces (the delay time) is longer than the total time the animal spends restrained or handled. Thus, these FCM levels reflect true resting baseline levels. In addition, to assess whether animals were subject to long-term chronic stress, we quantified the predicted consequences (Fig. 1), including reproductive suppression and loss of body mass. Finally, to probe stress axis functioning (a hormonal challenge), we used a number of tests that require a brief explanation. Injections of hormones (or their analogues) that are part of the normal stress response were used to measure an animal's stress response 
over a series of blood samples. Two steps were typically involved: the dexamethasone suppression test followed by the ACTH stimulation test. Dexamethasone (DEX), a synthetic GC agonist, should inhibit GC secretion through negative feedback mechanisms at the level of the pituitary by causing a reduction in ACTH release. If it does not, this result suggests that the HPA may have been subject to chronic stress. The ACTH stimulation test probes directly the capacity of the adrenals to release GCs; a stronger, more sustained response implies that the animal would also show a more robust stress response to natural stressors. In voles, rather than using a hormonal challenge, we used a standardized restraint test to examine their ability to respond to and recover from an artificial stressor. In this test, voles were confined temporarily in a small plexiglass tube and their acute stress response was measured at various points over their reproductive life as they aged.

The stress axis is multi-tasking throughout the life of an animal, and it is crucial to successful adaptation to environmental variation for four reasons. The first three focus on common responses of individuals within a species; the fourth, on between-species differences from the basic pattern. In all of these, the adrenals play a critical role through the production of the GC hormones. First, the stress axis is involved in normal day-to-day activities associated with the diurnal cycle of waking, such as increased locomotion, exploratory behavior, increased appetite, and foodseeking behavior (reviewed in Wingfield and Romero, 2001). Second, the stress response permits both shortterm adjustments in the face of acute stressors and longerterm adjustments to chronic stressors. Both maximize the chances of survival, but the latter can come with tradeoff costs, such as inhibition of reproduction, suppression of the immune system, and suppression of growth (Fig. 1) (Boonstra et al., 1998; Sapolsky et al., 2000). The acute response, the classic "fight or flight" reaction, is a generalized response to a wide variety of stressors, such as bouts of severe weather, physical stressors such as attacks by a conspecific or a predator, or psychological stressors such as the fear of an imminent attack (see the section on snowshoe hares and predation risk). Third, the stress axis can be permanently programmed during development because of stressors affecting the mother, and this programming may adapt the individual to new conditions it may experience during its lifetime (Sheriff and Love, 2013) (see the sections on snowshoe hares and red squirrels). Fourth, the stress axis is subject to evolutionary modification and equips species to succeed under different ecological contexts. Mammals span the gamut of life-history variation: many species have high reproductive rates, rapid development, and short life spans, while others have the opposite traits. In the former group, the stress axis functions to enhance reproduction and sacrifice survival, whereas in the latter, the opposite occurs (Boonstra, 2005) (and see the section on Arctic ground squirrels and red-backed voles). In addition to the above, we have also discovered how two other adrenal steroids have evolved to permit survival during the northern winters (see sections on Arctic ground squirrels and red squirrels).

\section{THE SNOWSHOE HARE CYCLE AND THE ROLE OF PREDATOR-INDUCED STRESS}

Snowshoe hare populations undergo regular cyclic fluctuations, with $8-10$ years between peak densities (Keith, 1963; Krebs et al., 2013). These cycles are separated into four phases (increase, peak, decline, and low), each of which can last several years, and the changes in population numbers reflect these phases. During the peak phase, numbers can reach densities as high as $200-300 / \mathrm{km}^{2}$, whereas during the low phase, densities can fall to less than $5 / \mathrm{km}^{2}$ (Hodges et al., 2001). As hare populations increase, so do those of their predators, but with a lag of one to two years. During the decline phase, the snowshoe hare population virtually collapses, and predators are the direct cause of $83 \%$ to $100 \%$ of hare deaths (Boutin et al., 1986; Hodges et al., 2001). Following the decline phase, hare populations remain low for two to five years even though predator numbers are low and vegetation ample (Krebs et al., 1995). Hare reproduction is also cyclic, reaching a maximum during the early increase phase, when hares have up to four litters, but then progressively decreasing to a nadir of two litters during the decline phase (Cary and Keith, 1979; Stefan and Krebs, 2001). Sinclair et al. (2003) found that in captivity, hares removed from different phases of the cycle continued to exhibit reproductive performance similar to that of their counterparts in the wild. Thus there is an intrinsic "memory" of these differences in reproduction that they carry with them into the optimal conditions of captivity.

The dominant hypothesis in the 1970s was that food shortages caused the hare cycle (Keith, 1990). The alternative suggestions were that predation or social interactions drove the cycle. Social interactions were largely rejected because hares are not territorial and show no significant spacing behaviour (Boutin, 1984). In the late 1980s and early 1990s, the detailed work of Keith (1990) and Krebs et al. $(1995,2014)$ showed that predators play a critical role in driving the cycle. Although Keith (1990) argued that food shortages initiated the population decline which was then maintained by predation in a two-step manner, Krebs et al. (1995) found that food shortages occur in some but not all declining populations, and that the addition of food did not prevent the decline. They found that it was the interaction of food with predation that drove the hare cycle: their experimental findings showed that simultaneous removal of predators and addition of food resulted in much higher hare densities during the decline than resulted from either treatment alone.

These different hypotheses were reconciled by Hik's (1995) predator-sensitive foraging hypothesis, which proposed that hares are able to assess the risk of predation and modify their behaviour by using more protective habitats 
during the decline. Hares attempt to minimize their probability of getting killed by restricting their activity to areas of dense cover, but in doing so, they limit the quality and quantity of their food and thus experience a decline in body condition. Several authors (Wolff, 1980; Keith et al., 1984; Smith et al., 1988) had previously suggested that predation risk may influence patterns of habitat use by snowshoe hares. The consequence of the predator-sensitive foraging hypothesis is that hares trade off high reproduction (which requires good body condition) for survival during the population decline. However, Hodges et al. (2006) found that changes in body condition could not explain the changes in reproduction across the cycle. Furthermore, none of the above hypotheses could sufficiently explain the major enigma of the hare cycle, the low phase.

\section{Changes in Stress across the Cycle}

In 1993, Boonstra and Singleton took the first steps to understand these problems when they showed that hares were more stressed during the first year of the decline phase, having higher free cortisol levels (cortisol is the main GC in hares), lower CBG levels, and worse body condition than experimentally fed hares (Boonstra and Singleton, 1993). Boonstra et al. (1998) expanded upon this finding and tested whether hares during the decline phase were chronically stressed because of high predation risk whereas those during the low phase were not. Using a hormonal challenge protocol (see Primer section above), they found that during the 1990s decline, hares had higher baseline levels of free cortisol and reduced CBG levels, a greater cortisol response to the hormonal challenge (slight dexamethasone resistance followed by a more pronounced response to ACTH), increased glucose mobilization, lower leukocyte counts (lower immunity), and poorer body condition compared to hares during the low phase (Fig. 2). All of these changes indicated that hares were chronically stressed during the decline phase, and the authors argue that changes in predation risk alone were sufficient to explain these changes. Boonstra et al. (1998) hypothesized that their findings may also account for the lack of recovery of hares during the low phase because stress experienced by mothers is transmitted to their young and affects their fitness. Thus operating through maternal effects, predation risk may have long-term consequences for prey populations beyond the immediate effects of predators on prey behavior and physiology.

Beginning during the increase phase in 2005, Sheriff et al. set out to test this hypothesis. Using both a fecal cortisol metabolite (FCM) assay and the same hormonal challenge as Boonstra et al. (1998), Sheriff et al. (2011b) found that hares' stress levels reflected changes in predator numbers across the entire population cycle (Fig. 2). During the increase phase, when predator numbers were low, hares had lower FCM levels and better body condition. As hare and predator populations increased, hare FCM levels increased and their body condition worsened, with peak FCM
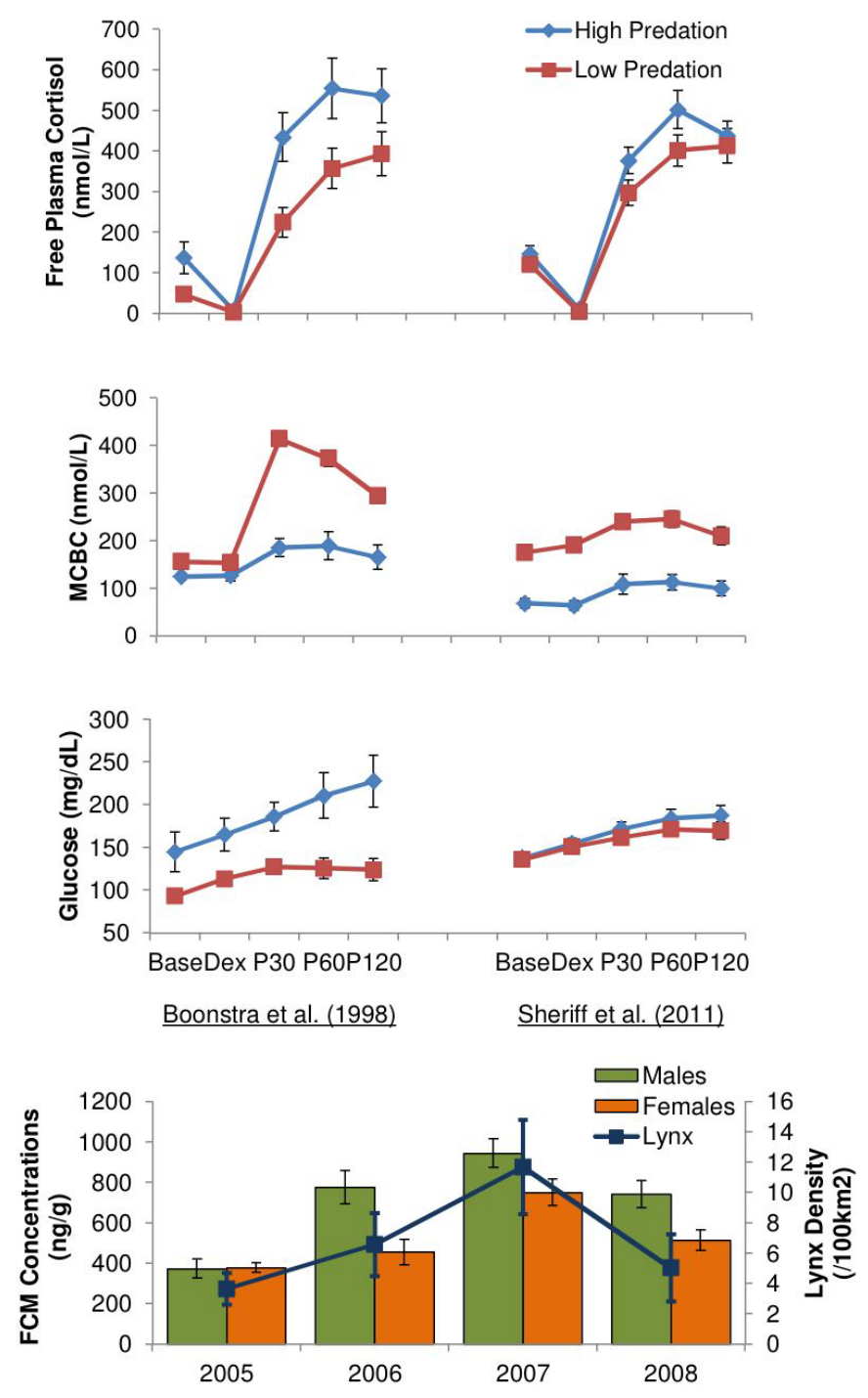

FIG. 2. Response over time in plasma concentrations (mean \pm SE) of free cortisol, maximum corticosteroid-binding capacity ( $\mathrm{MCBC}-$ a measure of CBG levels), and glucose to the hormonal challenge in snowshoe hares in high vs low predation years of two separate cycles (Boonstra et al., 1998; Sheriff et al., 2011b). Base values were those obtained at the initial bleed, DEX values were obtained $2 \mathrm{~h}$ after the dexamethasone injection, and P30, P60, and P120 values were obtained 30, 60, and 120 min, respectively, after the adrenocorticotropic hormone (ACTH) injection. Bottom: Also shown is the change in fecal cortisol metabolite (FCM) levels in snowshoe hares in relation to lynx density during the increase (2005), peak (2006), and decline $(2007,2008)$ phases of the second cycle. Figure adapted from Boonstra et al. (1998) and Sheriff et al. (2011b).

levels and the poorest body condition occurring during the decline phase, when predator numbers peaked. At that time, hares had higher baseline levels of plasma free cortisol and reduced CBG levels, a greater stress response to the hormonal challenge, greater energy reserves (gluconeogenesis causes catabolization of body tissues and their storage in the liver as rapidly mobilizable glycogen), and worse body condition. During the subsequent low phase, when predator numbers had declined, all these measures improved. These results support the hypothesis that hares are so highly sensitive to the risk of predation that increased risk results in chronically stressed hares. However, the results are 
correlative, and field experiments in which predators are either removed or added would provide a definitive causeeffect relationship between the two. Predator removal has been carried out (Hodges et al., 2006), and though the hormonal challenge was not carried out, the gain in body mass within the removal grid relative to the control grids supports the hypothesis.

Seasonal changes in the stress profile of hares complicate the picture. Sheriff et al. (2011b) argued that these are a result of an interactive effect of predation risk and food availability. As winter progresses, the hare:lynx ratio and food availability decline, and by late winter, when there are half as many hares per lynx and food quality is poorest (Sinclair et al., 1982; Sheriff et al., 2011b), hares had higher stress levels than in early winter. Within a breeding season, hares' stress levels were highest during the first litter (late May), declined during the second (late June-early July), and increased again during the third (early August). Between the first and second litters, predation risk declines and vegetation grows (in quality and quantity, increasing visual obstruction and hiding places). By the third litter, vegetation is starting to senesce, which leads to increased predation risk.

\section{The Impact of Maternal Stress during the Snowshoe Hare Cycle}

To elucidate how these changes in stress levels affected the snowshoe hare population cycle, Sheriff et al. investigated the role that maternal stress plays in reproduction and whether maternal stress has long-term intergenerational effects. Using both experimental and observational approaches, Sheriff et al. (2009) showed that predatorinduced increases in maternal stress reduce reproduction success: stressed mothers gave birth to fewer, smaller, and lighter babies. Moreover, mothers that had the highest FCM levels aborted or gave birth to stillborn babies. Of the mothers that gave birth to viable offspring, Sheriff et al. (2010) showed that increasing maternal FCM levels resulted in offspring that, at weaning and adulthood, had higher levels of plasma free cortisol, lower CBG levels, a greater stress response, and lower immunity (Fig. 3). When applied to the population level, these findings supported the hypothesis that the low phase of the snowshoe hare cycle was the result of the negative consequences of intergenerational, maternally-inherited stress originating during the decline phase and related to intense predation risk (Boonstra et al., 1998).

Three main avenues of study are still needed to fully understand the impact of stress and maternal stress effects on the snowshoe hare cycle. First, the mechanisms by which maternal stress is inherited from mother to daughter are not fully understood. A flurry of studies in disciplines ranging from biomedicine to evolutionary biology found that early life experiences can exert profound and lifelong "programming" effects on offspring (see review by Love et al., 2013). These programming effects often not only persist into adulthood but also can subsequently affect offspring in future generations via epigenetic mechanisms, which occur when the environment affects DNA structure and modifies gene expression or function (Meaney et al., 2007). Second, a clear field test is needed to show that maternal stress has intergenerational negative consequences, decreasing offspring reproduction. Lastly, a great deal of work is currently being done on the adaptive function of maternal stress effects (see review by Sheriff and Love, 2013). However, during the low phase of the snowshoe hare cycle, the intergenerational inheritance of stress can be viewed as a negative functional outcome. We propose that it is necessary to test the idea that these maternal stress effects are an adaptive functional outcome during the decline phase (increasing offspring anxiety and fearfulness without the necessity of encountering a predator) that increases offspring survival. These effects have likely evolved as adaptations to survive the decline phase, which is such a severe period that any negative outcomes in other phases of the cycle (such as lower reproduction at the beginning of the low phase) are irrelevant from an evolutionary perspective.

\section{THE STRESS OF SEX:}

\section{THE ROLE OF THE STRESS AXIS IN SUPPORTING REPRODUCTION IN ARCTIC GROUND SQUIRRELS}

Animals reproducing at high latitudes are faced with short summers, during which offspring need to grow and mature enough to be able to survive the long winters. In species that have slow-maturing young, reproduction occurs only once, early in the spring, when food is less abundant. This is the situation facing Arctic ground squirrels (AGS): males must awaken from hibernation, produce sperm, emerge into a still frozen and snow-covered landscape (Buck and Barnes, 1999a), and be ready to defend a territory encompassing as many female burrows as possible (Lacey and Wieczorek, 2001).

In the animal world, the strategies for defending territory and mates fall along a continuum ranging from physical combat to largely ritualized combat. Male AGS are decidedly at the physical end. Males fight aggressively, and virtually all males end up heavily wounded by the end of the breeding season (Delehanty and Boonstra, 2011). Most males suffer from multiple wounds, and wounding can be debilitating or even fatal (Gillis, 2003; Delehanty and Boonstra, 2011; Fig. 4). Thus, the short mating period of two to three weeks is a physically costly enterprise for males and appears to have survival implications. Less than $40 \%$ of males will survive to breed in a second season, and less than $1 \%$ breed in three or more seasons (estimated from figures in Gillis, 2003).

With low annual survival and a single, concentrated breeding season, life history theory predicts that males should maximize the energy that they can devote to current reproduction (Boonstra and Boag, 1992), and because the stress axis is one of the major physiological mechanisms for mobilizing stored energy, it has been the focus of our work 

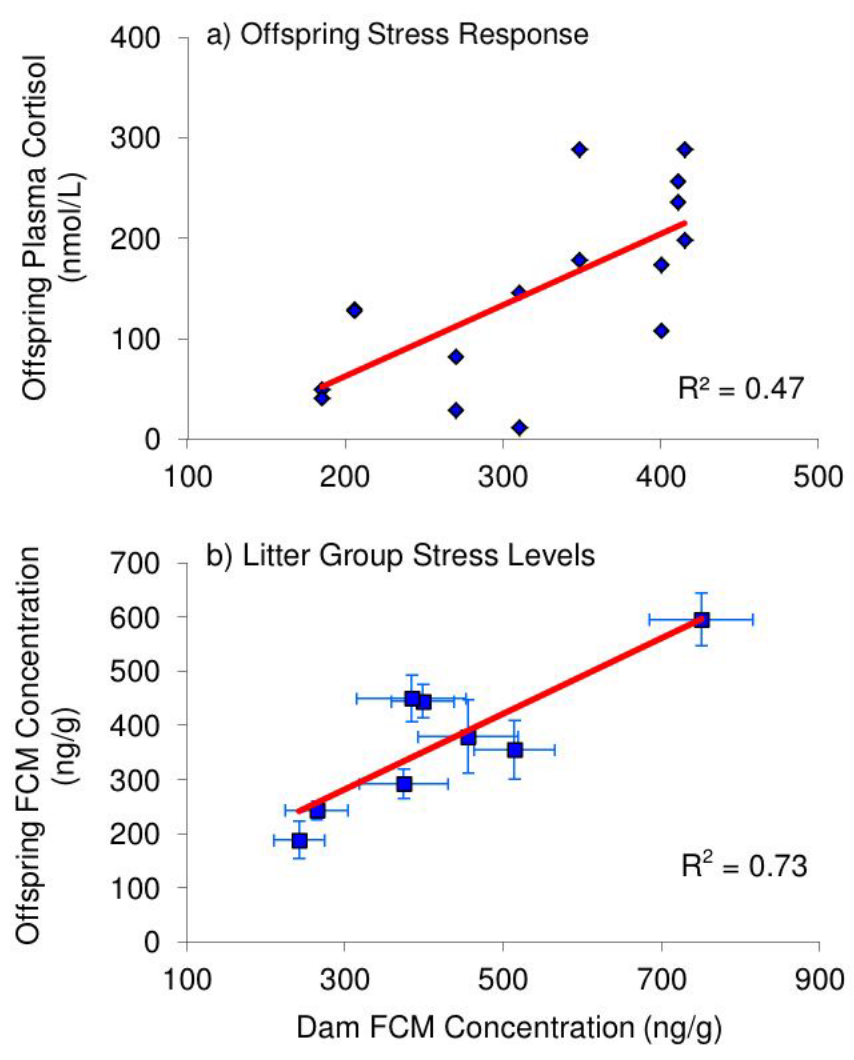

FIG. 3. Maternal fecal cortisol metabolite (FCM) levels and the resultant stress levels in 28-day-old offspring. (a) Individual maternal FCM levels and the free cortisol response of individual offspring born and raised in outdoor enclosures. From each hare mother, one male and one female offspring were randomly chosen. (b) The average adult female and corresponding average juvenile FCM levels for the first, second, and third litter groups in the wild from 2005 to 2008. Adapted from Sheriff et al. (2010b).

on Arctic ground squirrels. The potential for the stress axis to play a central role in reproduction is exemplified by a group of marsupial "mice" in Australia that live in highly seasonal environments. The males of at least 10 such species all die at the end of their first and only breeding season (a life history called semelparity), and the physiological solution that these animals have arrived at is to unleash their stress axis: they produce more GCs and less CBG, and there is a breakdown in the normal negative feedback system by which increasing GC levels act to halt further GC production (e.g., Bradley et al., 1980; Bradley, 1990). Lee and Cockburn (1985) hypothesized that catabolizing protein allows the males to fuel breeding efforts without having to forage during a time when food resources are scarce.

Male AGS also appear to have evolved a strategy in which the stress axis mobilizes energy to support reproduction but perhaps because they have a moderate chance of surviving to mate in a second year, their strategy is less extreme than the unrestrained GC production found in the semelparous marsupials. Their free GC response to stress (i.e., the amount of circulating GC not bound to $\mathrm{CBG}$ ) remains constant throughout the breeding and postreproductive seasons, but male AGS show a distinct trend in CBG levels. Plasma CBG levels are low in the prebreeding and breeding periods, but they climb steadily through

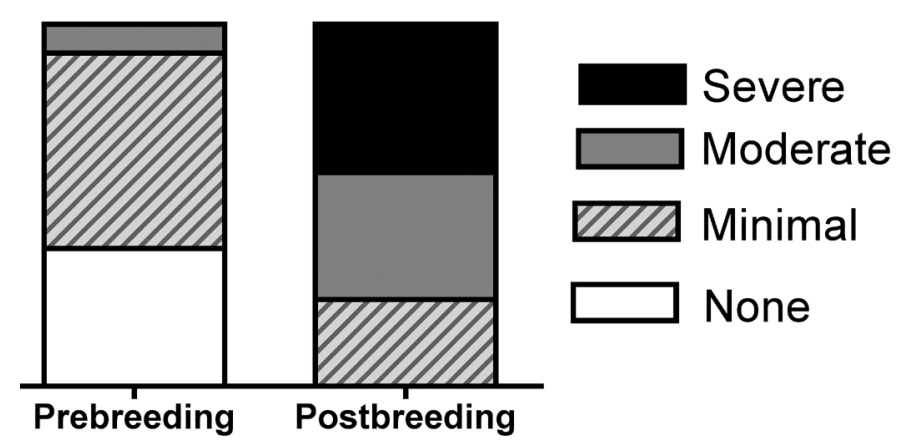

FIG. 4. Prevalence and severity of wounding in pre- and post-breeding male Arctic ground squirrels, expressed as proportions of all animals caught (prebreeding $\mathrm{n}=13$; post-breeding $\mathrm{n}=17$ ). Wounding was based on the number and size of wounds. Categories were: "None" for no wounds; "Minimal" for fewer than 10 punctures and less than $2 \mathrm{~cm}^{2}$ of externally visible wounding; "Moderate" for 10 or more punctures, 2 to $7 \mathrm{~cm}^{2}$ of externally visible wounding, or both; and "Severe" for more than $7 \mathrm{~cm}^{2}$ of externally visible wounding, significant damage to muscle, testes, or eyes, or both. Adapted from Delehanty and Boonstra (2011).

the spring and summer until they are about four times the breeding season levels (Boonstra et al., 2001a, b; Delehanty and Boonstra, 2011). On the basis of physiological evidence of chronic GC exposure over the course of the breeding season despite consistent free GC levels, we hypothesized (Delehanty and Boonstra, 2011) that true plasma baseline GC levels are elevated in the prebreeding and breeding season as a means of promoting the GC-mediated conversion of protein and fat into glucose and glycogen, which are stored in the liver as a rapid energy source during the breeding season (the "basal stress hypothesis"). Unfortunately, because we were unable to measure true baseline GC levels, we could not test this hypothesis directly. However, the hypothesis has found support in work by Sheriff et al. (2012), who measured fecal cortisol metabolites to measure relative GC exposure in Arctic ground squirrels from various elevations and habitats over the course of the summer. The advantage of measuring fecal cortisol metabolites is that it provides an integrated measure of GC exposure over a period of several hours, so that increases in GCs due to transient acute stressors (including capture) have little influence on the measurement (Sheriff et al., 2011a). Fecal cortisol metabolites are therefore likely to reflect true baseline GC levels in plasma. Sheriff et al. (2012) found that breeding season GC exposure was consistently elevated compared with levels over the rest of the summer. Thus, the increasing CBG over the summer (Boonstra et al., 2001a, b; Delehanty and Boonstra, 2011) is matched with decreasing baseline GC exposure (Sheriff et al., 2012), consistent with the basal stress hypothesis.

If this hypothesis is correct, then male AGS have apparently evolved a strategy of catabolizing fat and protein and converting them into glucose and glycogen in the liver before the stressors of the breeding season are encountered. Such a strategy fits well with the preparative hypothesis of Romero (2002), who considered various explanations for the observation that baseline GC levels fluctuate seasonally. His preparative hypothesis is that increases in baseline GCs 
perform a preparative function, which is defined as effects that modulate later responses to stressors (Sapolsky et al., 2000). Romero (2002) proposed that these seasonal increases in GCs could be priming the organism for adverse conditions it is about to encounter. He suggested that this strategy would be available to species that can predict certain stressors, such as competitive breeding seasons and the likelihood of adverse weather: exactly the situation facing male Arctic ground squirrels as they enter the breeding season.

However, a few more pieces of information are needed to confirm our understanding of the role that the stress axis is playing in male AGS reproductive strategies. First, the basal stress hypothesis works only if negative feedback is somehow suppressed during the breeding season. Under normal conditions, baseline GC levels are kept in check primarily by mineralocorticoid receptors (MRs) in the hippocampus (Fig. 1). As plasma GC levels increase, MRs and GRs at higher GC concentrations provide a negative feedback signal to the brain and pituitary that shuts down further GC production (de Kloet et al., 1999; Joëls et al., 2008). However, under the basal stress hypothesis, MR-mediated negative feedback should be virtually obliterated in order to allow basal GC levels to increase. Our work suggests that negative feedback at the level of the pituitary does not change (Delehanty and Boonstra, 2011), but we have not yet assessed MR and GR density in the brain.

The second essential piece of work will be to confirm cause and effect. The basal stress hypothesis supposes that low CBG levels and decreased negative feedback produce elevated GC levels in the absence of stressors. An alternative explanation for the patterns observed so far is that stressors in the early spring are suppressing CBG levels (McDonald et al., 1981; Bradley, 1987) and impairing negative feedback (McDonald et al., 1986; Bradley, 1990). As the season progresses, these stressors are eliminated, and both CBG levels and negative feedback return to "normal." For this alternative explanation to be plausible, the early-season stressors would have to be present prior to emergence above ground. Male AGS become euthermic in the early spring and remain underground for up to several weeks, consuming food that they cached in their burrows the previous fall (Barnes and Ritter, 1993). The basal stress hypothesis predicts that CBG levels will be low at this time and GC levels elevated. It is therefore necessary to try to measure GCs and $\mathrm{CBG}$ before emergence.

\section{STRESS PHYSIOLOGY OF NORTH AMERICAN RED SQUIRRELS}

Since 1985, the population dynamics of North American red squirrels in southwestern Yukon $\left(61^{\circ} \mathrm{N}, 138^{\circ} \mathrm{W}\right)$ have been monitored each year. Monitoring was initiated as a part of the Kluane Boreal Forest Ecosystem Project (1986-96: Krebs et al., 2001) and then continued as part of the Kluane Red Squirrel Project (www.redsquirrel.ca). These studies have provided many insights into both the natural history of red squirrels and fundamental questions in evolution, ecology, and energetics (Humphries and Boutin, 2000; Boutin et al., 2006; McAdam et al., 2007; Dantzer et al., 2013).

In 1996, Boonstra and colleagues began studying the stress physiology of free-living red squirrels in southwestern Yukon. Since then, they have measured true and nominal baseline total and free plasma GCs, maximum corticosteroid binding capacity (MCBC), and the effects of injections of DEX and ACTH on plasma cortisol levels. Although they did not control for the effects of phylogeny, Boonstra and McColl (2000) found that red squirrels had levels of total and free plasma cortisol and MCBC that were two to seven times higher than those found in Arctic ground squirrels at Kluane. Surprisingly, red squirrels were somewhat resistant to the effects of DEX. An injection of DEX caused their free cortisol levels to fall to $33 \%$ of baseline levels. In contrast, after a similar injection, free cortisol levels of Arctic ground squirrels and snowshoe hares fell to less than 5\% of baseline levels (Boonstra et al., 1998; Boonstra and McColl, 2000). However, despite their resistance to DEX, there was no evidence that the red squirrels were suffering from chronic stress (see the Primer section above for an explanation of DEX resistance). Although red squirrels may be similar to prairie voles (Microtus ochrogaster), in that they are resistant to the effects of DEX (Taymans et al., 1997), further study is required to determine the appropriate dose of DEX to reduce plasma cortisol levels.

We have carried out broad comparative analyses that integrate the above study on red squirrels (Boonstra and McColl, 2000) with studies of other mammals (Desantis et al., 2013). Compared with 17 other rodent species from four families (Caviidae, Cricetidae, Muridae, Sciuridae), red squirrels had total plasma cortisol levels that were higher than all but three rodent species. However, much of this cortisol was bound to high CBG levels; thus, only $15 \%$ of plasma cortisol was free, which was less than all but four of the 17 other rodent species. Red squirrels appear to fall on both ends of this comparative spectrum, having high total cortisol, but low free cortisol, and we do not understand what ecological problem has selected for this physiological solution.

Although the study by Boonstra and McColl (2000) described general parameters of the HPA axis in red squirrels, additional studies were limited by our inability to acquire true baseline plasma cortisol levels not affected by the stress of capture and handling (Sheriff et al., 2011a) and by the possible harmful effects associated with obtaining multiple plasma samples from the same individuals. One solution to these problems is to measure GC metabolite levels in fecal samples (FCMs) that are collected during routine live trapping. Although measuring FCMs possesses a number of advantages compared to measuring plasma samples, their use requires careful validation (Sheriff et al., 2011a), which we have done in the study of red squirrels (Dantzer et al., 2010). 
The development of this relatively non-invasive method to measure stress axis activity in red squirrels has provided an opportunity to investigate a variety of questions. One example is a recent study documenting how maternal stress responses to variation in population density induce an adaptive hormone-mediated maternal effect on offspring postnatal growth rates (Dantzer et al., 2013). Red squirrels in southwestern Yukon live in a variable environment. Episodic pulses of their major food source, seed from white spruce trees (LaMontagne and Boutin, 2007; Fletcher et al., $2010)$, generates interannual variation in population density (Boutin et al., 2006; Dantzer et al., 2012). These changes in population density have important effects on the lifehistory traits of female red squirrels. Under high-density conditions, only the fastest growing offspring are likely to survive to the following spring (i.e., recruit into the population: Dantzer et al., 2013). In a recent study, Dantzer et al. (2013) showed that pregnant female red squirrels use social cues in their environment that accurately reflect population density (frequency with which they hear territorial vocalizations) to adjust offspring growth rates according to the competitive density that they anticipate their offspring will encounter at independence (Fig. 5). Females that perceived increased density because of audio playbacks of territorial vocalizations called rattles produced offspring that grew significantly faster than those of control females (Fig. 5). Fast-growing offspring are favoured by natural selection as they are more likely to survive to the following spring (McAdam and Boutin, 2003; Dantzer et al., 2013), so these increases in offspring growth are adaptive. This result was surprising, given that these females perceiving increased density did not have access to additional food sources compared to control females. Even more surprising was the observation that females perceiving increased density produced offspring that grew as fast as those of females in high-density study areas (Fig. 5) that were provided with supplemental food. These observations suggest that plasticity of offspring growth is regulated by food abundance but also by the perceived benefits of producing fast-growing offspring.

Female red squirrels are able to achieve these adaptive increases in offspring growth through changes in maternal glucocorticoid levels. As in many other species (Creel et al., 2013), red squirrel females living under high-density conditions have significantly higher FCM levels (Dantzer et al., 2013). Experimental increases in actual or perceived population density confirm that increases in density cause increases in female FCM levels, and that these higher FCM levels are not caused by food shortages or changes in predator abundance (Dantzer et al., 2013). These changes in maternal FCM levels induced the adaptive increase in offspring growth because females with the highest FCM levels produced the fastest growing offspring and feeding females GCs caused them to produce faster growing offspring (Fig. 6). The combined evidence from all aspects of this study indicates that stress responses of female red squirrels to population density induced an adaptive increase in

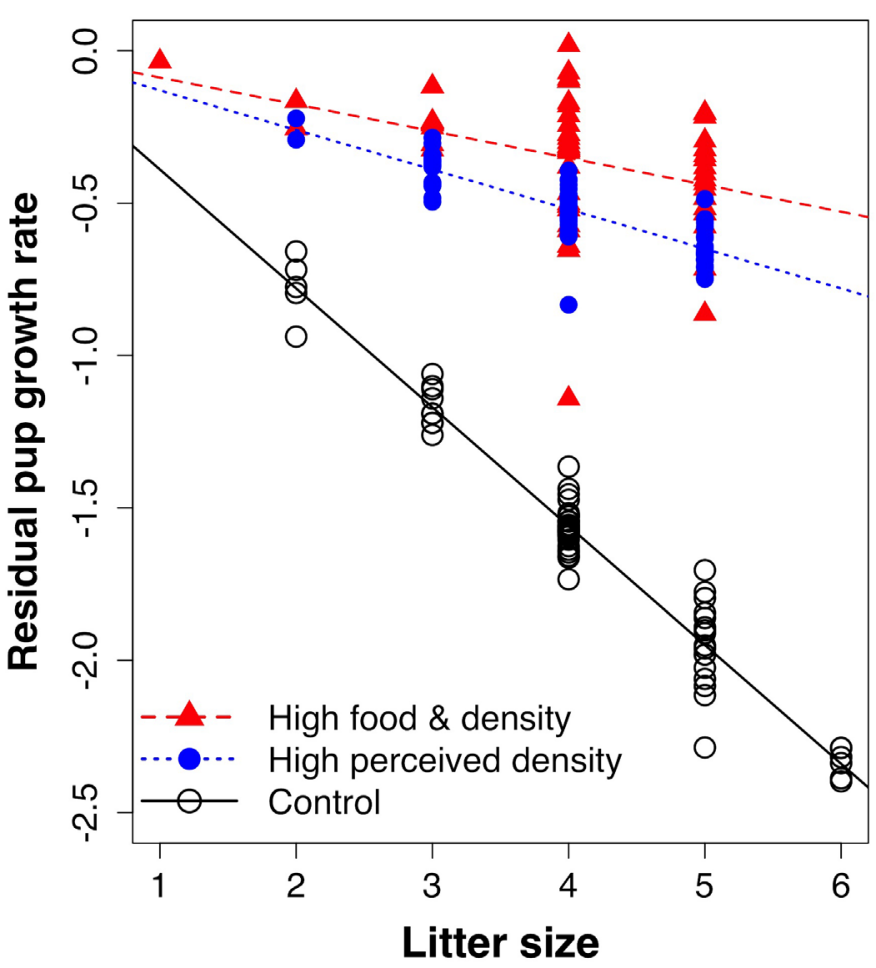

FIG. 5. Female red squirrels that were exposed to experimentally increased population density and supplemental food ("High food \& density") and those exposed to audio playbacks of territorial vocalizations of red squirrels mimicking high-density conditions ("High perceived density") produced offspring that grew significantly faster than those of control females ("Control"). Values on the y-axis represent residuals from a linear-mixed effects model. From Dantzer et al. (2013) Science 340:1215-1217. Reprinted with permission from AAAS.

offspring growth. Thus, these maternal stress responses induced adaptive plasticity in offspring characteristics for the environment mothers anticipated their offspring would encounter (i.e., an adaptive maternal effect; Marshall and Uller, 2007).

\section{GROWING OLD IN THE BOREAL FOREST: AGING IN THE RED-BACKED VOLE}

All animals in nature, whether they live in the boreal forest or the tropics, are expected to show the progressive effects of aging; the genes causing those effects benefit the animals when they are younger and reproducing, but come at a cost when they are older. Most small mammals, such as voles and lemmings, live short lives (maximally only about one year), and none breed in two successive years (see Boonstra, 1994, and references therein). This pattern results from high mortality owing to both biotic factors (e.g., competitors, disease, predators) and abiotic factors (e.g., severe weather). Aging theory predicts that species that experience high rates of environmentally imposed mortality should show a rapid age-related deterioration of physiological function, but only after they start reproducing (Williams et al., 2006). Because reproduction is costly and energy is limiting, animals are predicted to trade off 


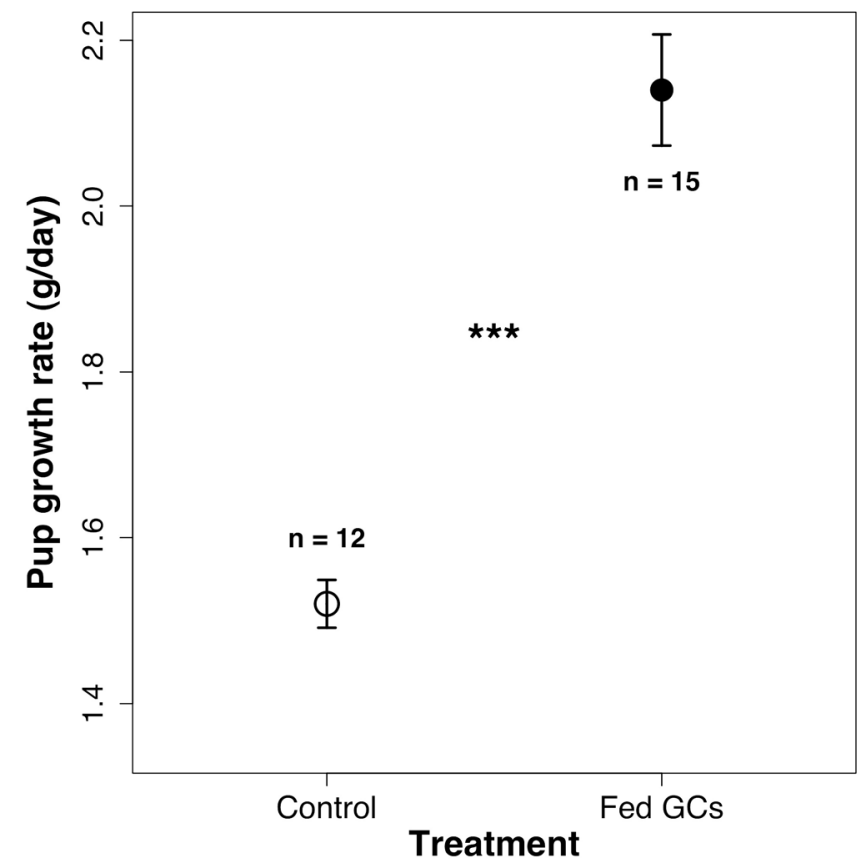

FIG. 6. Offspring born to female red squirrels that were fed small dosages of stress hormones ("Fed GCs") dissolved in peanut butter grew significantly faster than those born to females fed plain peanut butter. Raw offspring growth rates are shown on the y-axis, and sample sizes (number of pups) are indicated. From Dantzer et al. (2013) Science 340:1215-1217. Reprinted with permission from AAAS.

the investment in the maintenance of body tissue for investment in reproduction (Kirkwood and Austad, 2000). In free-ranging animals, tests of the evolutionary hypotheses of aging (also called senescence) have focused almost solely on age-related declines in survival and reproductive success ("actuarial senescence"). These tests demonstrate that both short- and long-lived invertebrate and vertebrate species experience actuarial senescence (reviewed in Nussey et al., 2013). However, our knowledge of physiological aging in free-ranging animals is extremely limited (Nussey et al., 2013). In our research (Fletcher, 2005), we addressed this issue by focusing on the deterioration of the stress axis in free-living northern red-backed voles. These voles live throughout the boreal forests of northern Canada and Eurasia (Boonstra and Krebs, 2012).

Research on aging in laboratory rodents (e.g., Sapolsky et al., 1986) and humans (e.g., Lupien et al., 1998; Hertoghe, 2004; Otte et al., 2005) has focused heavily on the deterioration of the HPA axis as a key integrator of numerous physiological functions (Fig. 1). On the basis of the findings from these model systems, we predicted age-dependent (1) increases in baseline glucocorticoids levels; (2) impairment in the ability to recover rapidly from an acute stressor; and (3) declines in GR and MR receptor levels at key regulatory sites in the brain (hippocampus, hypothalamus, and pituitary) in free-living red-backed voles. To examine predictions (1) and (2), we exposed the same vole repeatedly over its reproductive lifespan to a standardized restraint test (see Primer on the HPA axis). In total, we performed 125 restraint stress tests on 58 different adult male voles, of which 32 were exposed to multiple restraint stress tests (Fletcher, 2005). In these restraint stress tests, we quantified levels of total corticosterone (the dominant glucocorticoid in voles), CBG, and free corticosterone. Simultaneously we also quantified a general condition indicator (haematocrit) (e.g., Hellgren et al., 1993; Boonstra et al., 1998). To examine prediction (3), we sacrificed reproductively active voles at three times over the breeding season (early, mid, and late) to examine changes in brain organization measured as the expression of receptor levels of GR and MR.

We found little evidence of age-dependent deterioration in the HPA axis (Fletcher, 2005; Q.E. Fletcher et al., unpubl. data). Though total corticosterone increased with age, $\mathrm{CBG}$ also increased, resulting in no increase in baseline levels of free corticosterone. Moreover, in contrast to the predictions, older males were able to return to their baseline corticosterone levels following the restraint stress test more rapidly than younger males. This result was corroborated by the evidence that there was no change with age in GR and MR levels in regions throughout the brain. Thus we saw no evidence of an age-dependent deterioration of the HPA axis. However, we did find a decline in condition with age, indicating that the general physiological state of breeding male voles was declining. Thus different physiological systems may age at different rates. We postulate that a highly functioning HPA axis is a prerequisite for sustaining life, with any age-dependent deterioration likely to cause a substantial increase in the risk of death. Thus such a deterioration would be strongly selected against. In contrast, the deterioration in general condition after the onset of reproduction causes a modest increase in the risk of death, reflecting the tradeoff between investing in reproduction versus maintaining the body in peak physiological state.

\section{HORMONAL STRATEGIES TO SURVIVE THE NORTHERN WINTER}

There are four options northern mammals adopt to survive winter: either leave, endure (remain active above the snow), remain active under the snow, or hibernate (Boonstra, 2004). The principal threats to winter survival are starvation and low temperatures, both of which may be aggravated by high predation risk. For all four options, preparation prior to winter is critical. We examined the hormonal strategies of a hibernator, the Arctic ground squirrel, and of an endurer, the red squirrel. As with the stress response, the adrenals play a key role in these strategies.

\section{Arctic Ground Squirrels and Preparing for Hibernation}

Hibernation, or adopting a comatose-like state for up to eight to nine months per year (interrupted by periodic arousals), would seem to be the ideal winter strategy. To minimize the energy consumption of fat stores, hibernators should ideally seek a hibernaculum below the frost line, with a temperature of about $0^{\circ} \mathrm{C}$. AGS are obligate 
hibernators and are found in North America throughout the Arctic tundra, Arctic alpine, and northwestern boreal forest meadows. However, ideal hibernacula do not exist for AGS, and they are forced to hibernate just above permafrost in hibernacula where temperatures can reach $-23^{\circ} \mathrm{C}$ (Buck and Barnes, 1999b). At $0^{\circ} \mathrm{C}$, the primary metabolic fuel is lipid, and it provides both energy from the catabolism of fatty acids and sufficient glucose for certain critical tissues such as the brain, heart, and erythrocytes. However, at subzero hibernaculum temperatures, AGS have metabolic rates up to 16 times that at $0^{\circ} \mathrm{C}$ (Buck and Barnes, 2000). In addition, the limited glucose derived from catabolism of lipids is now insufficient and must be supplemented by the formation of new glucose from muscle breakdown (Buck and Barnes, 2000). The problem for these squirrels is how to build the needed muscle tissue in summer that they can then catabolize in winter.

Our evidence indicates that Arctic ground squirrels have evolved a solution seen in no other known mammal: they exploit the benefits of high androgen levels produced by the adrenals (rather than the gonads) to build muscle in the summer prior to hibernation (Boonstra et al., 2011). Both sexes and all age groups produce high levels of testosterone and related anabolic steroids in summer (Fig. 7a, adult females have significantly lower [but still high] levels for reasons discussed in Boonstra et al., 2011). These high levels result in a $20 \%-30 \%$ increase in lean muscle mass from the end of the reproductive period to the beginning of hibernation, which is then consumed overwinter (Boonstra et al., 2011; Sheriff et al., 2013). In contrast, the Columbian ground squirrel (U. columbianus), a closely related species from southern Alberta that hibernates at about $0^{\circ} \mathrm{C}$, has low androgen levels in both sexes and all age groups in summer and shows a negligible increase in lean mass over summer and decrease over winter. Two critical tests remain to be done. The first is to test this hypothesis by removing adrenal androgens in AGS and assessing the subsequent changes in muscle mass and in overwinter survival. The second is to test whether androgen receptors are present only in muscle in pre-hibernating AGS, but not in any other tissue in which they are normally present. The benefits of high testosterone and other anabolic steroid levels (aggressive and sexual behaviour, spermatogenesis, secondary sex characteristics, muscle hypertrophy, and reduced response to pain) normally come with costs (immunosuppression, higher energetic demands, and reduced paternal behavior) (Wingfield et al., 2001). Thus, have AGS avoided paying these costs by detecting the plasma androgens only in muscle tissue?

\section{The Territorial Imperative in Winter: The Red Squirrel Solution}

In many species, territorial behaviour is limited to the breeding season and is tightly coupled to circulating gonadal steroid levels; however, non-breeding seasonal aggression and territoriality are common in many

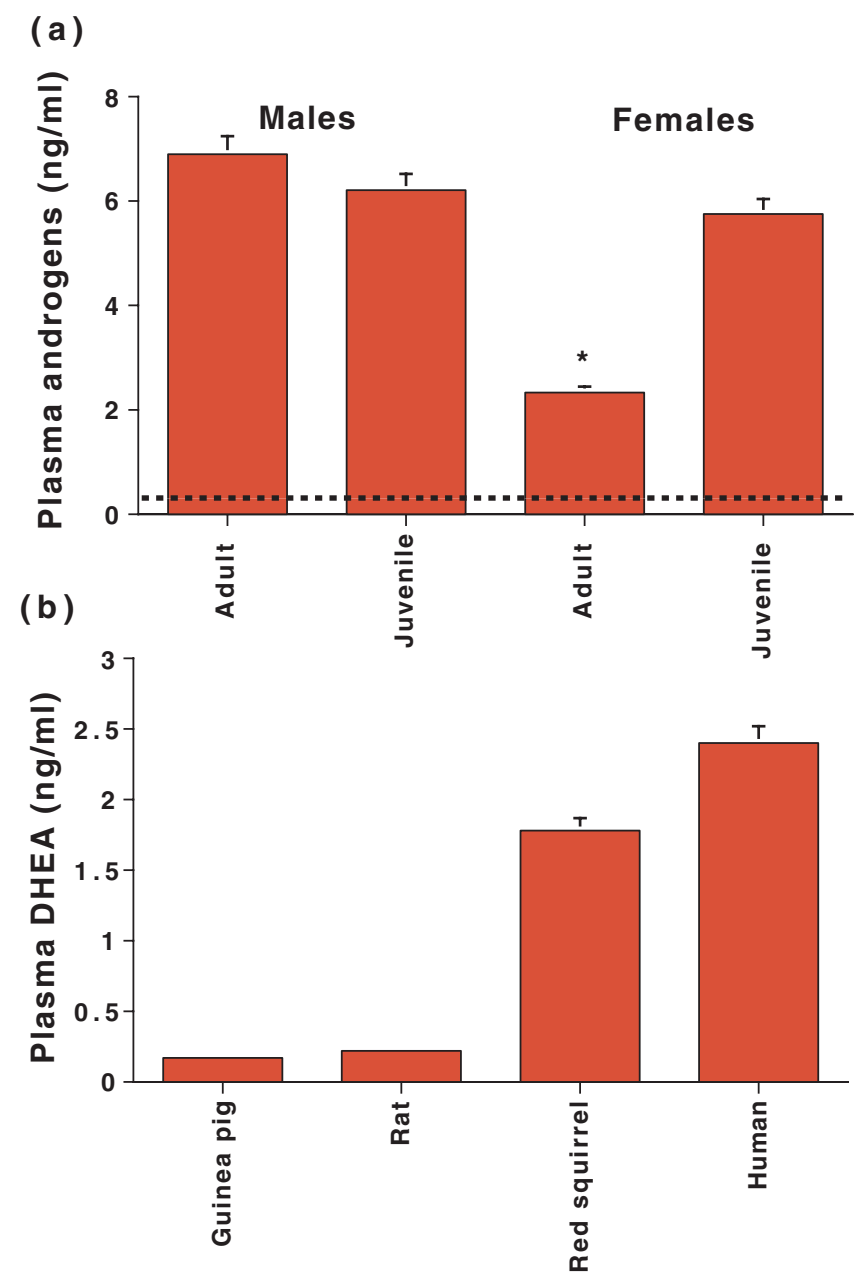

FIG. 7. (a) Plasma androgen levels (means \pm SE) in Arctic ground squirrels in late summer prior to hibernation. Adult females have significantly lower levels than the other three groups $(\mathrm{F}=9.35$, df 3,31, $p<0.0001)$. The dashed horizontal line indicates the average level of plasma androgens found in prehibernating Columbian ground squirrels, a species from southern Alberta that does not hibernate on permafrost (data from Boonstra et al., 2011). (b) DHEA levels (means $\pm \mathrm{SE}$ ) from three rodents (laboratory guinea pigs, laboratory rats, and wild red squirrels) and one primate (humans). The red squirrel data come from Boonstra et al. (2008) and the remainder from Bélanger et al. (1989).

mammals. Yet for virtually all, the hormonal basis for this behaviour is unknown. Winter is a time of severe food limitation and extreme temperatures, and territorial defense of food stores permits winter survival. Throughout the boreal and northern forests of North America, both male and female red squirrels are highly aggressive in the non-breeding seasons in defense of food stores on their individual territories (Dantzer et al., 2012). We discovered that both sexes have moderately high concentrations of dehydroepiandrosterone (DHEA), an androgen precursor (Boonstra et al., 2008). DHEA is secreted from the adrenal cortex in some mammals such as primates (it is the most abundant steroid in human plasma; Labrie et al., 2005) and has been linked to aggression in non-breeding songbirds (Soma, 2006). The concentrations in the Yukon red squirrels were markedly higher than those in laboratory rats and guinea pigs and similar to plasma concentrations in some primates, 
such as humans (Fig. 7b). DHEA levels showed both seasonal variation, being higher in winter and late summer than in other seasons, and interannual variation. DHEA levels increase under stress. Levels are positively related to density, which suggests that territorial conflict drives levels up. Our evidence suggests that the source of this DHEA is also adrenal, as it increases markedly in response to an ACTH injection. The advantage of using DHEA (rather than gonadal steroids) as the underlying basis for territorial behaviour is that DHEA acts as a pro-hormone. It has no effect on body tissues until it reaches its targets such as the brain, where it can be converted by the necessary enzymes to the active steroid, estradiol (Soma, 2006). In contrast, the use of gonadal steroids such as testosterone would have compromised survival because of their negative effects on the immune system, increased energy mobilization, and increased muscle growth (Wingfield et al., 2001). This is the first examination of plasma DHEA concentrations in a wild rodent and the first field experiment on the regulation of plasma DHEA in any wild mammal. These data lay the foundation for future studies on the role of DHEA in nonbreeding spacing behaviour and territoriality in this and other mammal species.

\section{FUTURE DIRECTIONS AND UNKNOWNS}

Animals living in the boreal forest are exquisitely adapted to all the natural stressors, no matter how severe. Some of the responses to such stressors, such as that to intense predation risk by snowshoe hares, exact long-term costs, but even here their adaptations are evident. Some of our discoveries (such as the discovery of DHEA in red squirrels and of adrenal androgens in pre-hibernation Arctic ground squirrels) were serendipitous, yet allow for profound insights. Like all research, our findings over these last two decades raise additional questions that need to be tackled. Here are six of the key ones. First, the low phase of the snowshoe hare cycle appears to be related to maternal programming by the stress of high predation risk. We need to understand the basis of this programming, and epigenetic changes appear to be the most plausible mechanism. Second, we need to understand in greater detail how the stress axis of Arctic ground squirrels functions before, during, and after the breeding season. Third, female red squirrels are able to assess the competitive density that their offspring will encounter at independence and adjust offspring growth to maximize their chances of survival. We need to understand whether mothers adjust other characteristics of their offspring and the basis of these adjustments in the offspring phenotype, as it may also be epigenetic. Fourth, red-backed voles do not show a deterioration with age in the functioning of the HPA axis, unlike laboratory rodent models. Is the stress axis so crucial to existence that such a deterioration is not seen in any wild vertebrate? Fifth, Arctic ground squirrels prior to hibernation have high levels of adrenal androgens. Have they evolved so that only muscle "sees" this signal by having androgen receptor activation there and in no other tissue? Finally, if DHEA is the basis for nonbreeding season territoriality in red squirrels, does this link apply to all other species that engage in spacing behavior to protect critical resources during the season of food scarcity? The great unknown is how boreal forest animals will respond to stressors that are not natural, such as climate change at the rate and magnitude with which it is occurring. The stress axis will play a vital role if they are to cope, and we do not have an understanding of the degree of plasticity within the animals to respond. All of these species have experienced major changes in climate and vegetation repeatedly over the last 1.8 million years of glacial advance and retreat during the Pleistocene. The difference this time will be the speed at which change will happen and possibly how pervasive it will be.

\section{ACKNOWLEDGEMENTS}

All authors have contributed equally to the preparation of this paper. We thank all those colleagues, graduate students, technicians, and undergraduates who helped in carrying out both the field work at Kluane and the lab work at the Centre for the Neurobiology of Stress. We thank the Arctic Institute of North America, University of Calgary, for providing facilities at the Kluane Lake Research Station and the managers, Andy and Carol Williams, Sian Williams, and Lance Goodwin, for their care of us and for meeting our needs. We thank the reviewers of the manuscript who have improved this paper greatly. We thank Caitlin Riebe for the artistic rendering of Figure 1. This research was supported by grants and scholarships from the Natural Sciences and Engineering Research Council of Canada, the EJLB Foundation (now Echo Foundation), the Northern Scientific Training Program, and the International Polar Year.

\section{REFERENCES}

Barnes, B.M., and Ritter, D. 1993. Patterns of body temperature change in hibernating Arctic ground squirrels. In: Carey, C., Florant, G.L., Wunder, B.A., and Horwitz, B., eds. Life in the cold: Ecological, physiological, and molecular mechanisms. Boulder: Westview Press. 119-130.

Bélanger, B., Bélanger, A., Labrie, F., Dupont, A., Cusan, L., and Monfette, G. 1989. Comparison of residual C-19 steroids in plasma and prostatic tissue of human, rat and guinea pig after castration: Unique importance of extratesticular androgens in men. Journal of Steroid Biochemistry 32(5):695-698. http://dx.doi.org/10.1016/0022-4731(89)90514-1

Boonstra, R. 1994. Population cycles in microtines: The senescence hypothesis. Evolutionary Ecology 8(2):196-219. http://dx.doi.org/10.1007/BF01238250

- 2004. Coping with changing northern environments: The role of the stress axis in birds and mammals. Integrative \& Comparative Biology 44(2):95-108.

http://dx.doi.org/10.1093/icb/44.2.95 
2005. Equipped for life: The adaptive role of the stress axis in male mammals. Journal of Mammalogy 86(2):236-247. http://dx.doi.org/10.1644/BHE-001.1

Boonstra, R., and Boag, P.T. 1992. Spring declines in Microtus pennsylvanicus and the role of steroid hormones. Journal of Animal Ecology 61(2):339-352.

http://dx.doi.org/10.2307/5326

Boonstra, R., and Krebs, C.J. 2012. Population dynamics of red-backed voles (Myodes) in North America. Oecologia 168(3):601-620.

http://dx.doi.org/10.1007/s00442-011-2120-z

Boonstra, R., and McColl, C.J. 2000. Contrasting stress response of male Arctic ground squirrels and red squirrels. Journal of Experimental Zoology 286(4):390-404.

http://dx.doi.org/10.1002/(SICI)1097-010X(20000301)286:4 $<390:: A I D-J E Z 7>3.0 . C O ; 2-O$

Boonstra, R., and Singleton, G.R. 1993. Population declines in the snowshoe hare and the role of stress. General and Comparative Endocrinology 91(2):126-143.

http://dx.doi.org/10.1006/gcen.1993.1113

Boonstra, R., Hik, D., Singleton, G.R., and Tinnikov, A. 1998. The impact of predator-induced stress on the snowshoe hare cycle. Ecological Monographs 68(3):371-394.

http://dx.doi.org/10.1890/0012-9615(1998)068[0371:TIOPIS]2. $0 . \mathrm{CO} ; 2$

Boonstra, R., Hubbs, A.H., Lacey, E.A., and McColl, C.J. 2001a. Seasonal changes in glucocorticoid and testosterone concentrations in free-living Arctic ground squirrels from the boreal forest of the Yukon. Canadian Journal of Zoology 79(1):49-58.

http://dx.doi.org/10.1139/z00-175

Boonstra, R., McColl, C.J., and Karels, T.J. 2001b. Reproduction at all costs: The adaptive stress response of male Arctic ground squirrels. Ecology 82(7):1930-1946.

http://dx.doi.org/10.1890/0012-9658(2001)082[1930:RAACTA ]2.0.CO;2

Boonstra, R., Lane, J.E., Boutin, S., Bradley, A., Desantis, L., Newman, A.E.M., and Soma, K.K. 2008. Plasma DHEA levels in wild, territorial red squirrels: Seasonal variation and effect of ACTH. General and Comparative Endocrinology 158(1):61-67. http://dx.doi.org/10.1016/j.ygcen.2008.05.004

Boonstra, R., Bradley, A.J., and Delehanty, B. 2011. Preparing for hibernation in ground squirrels: Adrenal androgen production in summer linked to environmental severity in winter. Functional Ecology 25:1348-1359.

http://dx.doi.org/10.1111/j.1365-2435.2011.01890.x

Boutin, S. 1984. Effect of late winter food addition on numbers and movements of snowshoe hares. Oecologia 62:393-400.

Boutin, S., Krebs, C.J., Sinclair, A.R.E., and Smith, J.N.M. 1986. Proximate causes of losses in a snowshoe hare population. Canadian Journal of Zoology 64(3):606-610.

http://dx.doi.org/10.1139/z86-090

Boutin, S., Wauters, L.A., McAdam, A.G., Humphries, M.M., Tosi, G., and Dhondt, A.A. 2006. Anticipatory reproduction and population growth in seed predators. Science 314(5807):1928-1930.

http://dx.doi.org/10.1126/science. 1135520
Bradley, A.J. 1987. Stress and mortality in the red-tailed phascogale, Phascogale calura (Marsupialia: Dasyuridae). General and Comparative Endocrinology 67(1):85-100.

. 1990. Failure of glucocorticoid feedback during breeding in the male red-tailed phascogale Phascogale calura (Marsupialia, Dasyuridae). Journal of Steroid Biochemistry and Molecular Biology 37(1):155-163.

http://dx.doi.org/10.1016/0960-0760(90)90384-W

Bradley, A.J., McDonald, I.R., and Lee, A.K. 1980. Stress and mortality in a small marsupial (Antechinus stuartii, Macleay). General and Comparative Endocrinology 40(2):188-200. http://dx.doi.org/10.1016/0016-6480(80)90122-7

Breuner, C.W., Delehanty, B., and Boonstra, R. 2013. Evaluating stress in natural populations of vertebrates: Total CORT is not good enough. Functional Ecology 27(1):24-36.

http://dx.doi.org/10.1111/1365-2435.12016

Buck, C.L., and Barnes, B.M. 1999a. Annual cycle of body composition and hibernation in free-living Arctic ground squirrels. Journal of Mammalogy 80(2):430-442.

http://dx.doi.org/10.2307/1383291

- 1999b. Temperatures of hibernacula and changes in body composition of Arctic ground squirrels over winter. Journal of Mammalogy 80(4):1264-1276.

http://dx.doi.org/10.2307/1383177

— 2000. Effects of ambient temperature on metabolic rate, respiratory quotient, and torpor in an Arctic hibernator. American Journal of Physiology. Regulatory, Integrative, and Comparative Physiology 279(1):R255-262.

Cary, J.R., and Keith, L.B. 1979. Reproductive change in the 10year cycle of snowshoe hares. Canadian Journal of Zoology 57(2):375-390.

http://dx.doi.org/10.1139/z79-044

Creel, S., Dantzer, B., Goymann, W., and Rubenstein, D.R. 2013. The ecology of stress: Effects of the social environment. Functional Ecology 27(1):66-80. http://dx.doi.org/10.1111/j.1365-2435.2012.02029.x

Dantzer, B., McAdam, A.G., Palme, R., Fletcher, Q.E., Boutin, S., Humphries, M.M., and Boonstra, R. 2010. Fecal cortisol metabolite levels in free-ranging North American red squirrels: Assay validation and the effects of reproductive condition. General and Comparative Endocrinology 167(2):279-286. http://dx.doi.org/10.1016/j.ygcen.2010.03.024.

Dantzer, B., Boutin, S., Humphries, M.M., and McAdam, A.G. 2012. Behavioral responses of territorial red squirrels to natural and experimental variation in population density. Behavioral Ecology and Sociobiology 66(6):865-878. http://dx.doi.org/10.1007/s00265-012-1335-2

Dantzer, B., Newman, A.E.M., Boonstra, R., Palme, R., Boutin, S., Humphries, M.M., and McAdam, A.G. 2013. Density triggers maternal hormones that increase adaptive offspring growth in a wild mammal. Science 340(6137):1215-1217. http://dx.doi.org/10.1126/science.1235765

de Kloet, E.R., Oitzl, M.S., and Joëls, M. 1999. Stress and cognition: Are corticosteroids good or bad guys? Trends in Neurosciences 22(10):422-426. http://dx.doi.org/10.1016/S0166-2236(99)01438-1 
Delehanty, B., and Boonstra, R. 2011. Coping with intense reproductive aggression in male Arctic ground squirrels: The stress axis and its signature tell divergent stories. Physiological and Biochemical Zoology 84(4):417-428.

http://dx.doi.org/10.1086/660809

Desantis, L.M., Delehanty, B., Weir, J.T., and Boonstra, R. 2013. Mediating free glucocorticoid levels in the blood of vertebrates: Are corticosteroid-binding proteins always necessary? Functional Ecology 27(1):107-119. http://dx.doi.org/10.1111/1365-2435.12038

Fletcher, Q.E. 2005. Physiological aging in a natural population of northern red-backed voles (Clethrionomys rutilus). MSc thesis, University of Toronto, Toronto, Ontario.

Fletcher, Q.E., Boutin, S., Lane, J.E., LaMontagne, J.M., McAdam, A.G., Krebs, C.J., and Humphries, M.H. 2010. The functional response of a hoarding seed predator to mast seeding. Ecology 91(9):2673-2683.

http://dx.doi.org/10.1890/09-1816.1

Gillis, E.A. 2003. Breeding, dispersal, male mating tactics, and population dynamics of Arctic ground squirrels. PhD thesis, University of British Columbia, Vancouver, British Columbia.

Hellgren, E.C., Rogers, L.L., and Seal, U.S. 1993. Serum chemistry and hematology of black bears: Physiological indices of habitat quality or seasonal patterns? Journal of Mammalogy 74(2):304-315.

http://dx.doi.org/10.2307/1382385

Hertoghe, T. 2004. The "multiple hormone deficiency" theory of aging: Is human senescence caused mainly by multiple hormone deficiencies? Annals of the New York Academy of Sciences 1057:448-465.

Hik, D.S. 1995. Does risk of predation influence population dynamics? Evidence from the cyclic decline of snowshoe hares. Wildlife Research 22(1):115-129. http://dx.doi.org/10.1071/WR9950115

Hodges, K.E., Krebs, C.J., Hik, D.S., Stefan, C.I., Gillis, E.A., and Doyle, C.E. 2001. Snowshoe hare demography. In: Krebs, C.J., Boutin, S., and Boonstra, R., eds. Ecosystem dynamics of the boreal forest: The Kluane Project. New York: Oxford University Press. $141-178$.

Hodges, K.E., Boonstra, R., and Krebs, C.J. 2006. Overwinter mass loss of snowshoe hares in the Yukon: Starvation, stress, adaptation or artefact? Journal of Animal Ecology 75(1):1 - 13 . http://dx.doi.org/10.1111/j.1365-2656.2005.01018.x

Humphries, M.M., and Boutin, S. 2000. The determinants of optimal litter size in free-ranging red squirrels. Ecology 81(10):2867-2877.

http://dx.doi.org/10.1890/0012-9658(2000)081[2867:TDOOLS] 2.0.CO;2

Joëls, M., Karst, H., DeRijk, R., and de Kloet, E.R. 2008. The coming out of the brain mineralocorticoid receptor. Trends in Neurosciences 31(1): $1-7$. http://dx.doi.org/10.1016/j.tins.2007.10.005

Keith, L.B. 1963. Wildlife's ten-year cycle. Madison: University of Wisconsin Press.

- 1990. Dynamics of snowshoe hare populations. Current Mammalogy 2:119-175.
Keith, L.B., Cary, J.R., Rongstad, O.J., and Brittingham, M.C. 1984. Demography and ecology of a declining snowshoe hare population. Wildlife Monographs 90. 43 p.

Kirkwood, T.B.L., and Austad, S.N. 2000. Why do we age? Nature 408:233-238.

http://dx.doi.org/10.1038/35041682

Krebs, C.J., Boutin, S., Boonstra, R., Sinclair, A.R.E., Smith, J.N.M., Dale, M.R.T., Martin, K., and Turkington, R. 1995. Impact of food and predation on the snowshoe hare cycle. Science 269(5227):1112-1115.

http://dx.doi.org/10.1126/science.269.5227.1112

Krebs, C.J., Boutin, S., and Boonstra, R., eds. 2001. Ecosystem dynamics of the boreal forest: The Kluane Project. New York: Oxford University Press.

Krebs, C.J., Kielland, K., Bryant, J., O’Donoghue, M., Doyle, F., McIntyre, C., DiFolco, D., et al. 2013. Synchrony in the snowshoe hare (Lepus americanus) cycle in northwestern North America, 1970-2012. Canadian Journal of Zoology 91(8):562-572. http://dx.doi.org/10.1139/cjz-2013-0012

Krebs, C.J., Boonstra, R., Boutin, S., Sinclair, A.R.E., Smith, J.N.M., Gilbert, B.S., Martin, K., O’Donoghue, M., and Turkington, R. 2014. Trophic dynamics of the boreal forests of the Kluane region. Arctic (KLRS 50th Anniversary Issue). http://dx.doi.org/10/14430/arctic4350

Labrie, F., Luu-The, V., Bélanger, A., Lin, S.-X., Simard, J., Pelletier, G., and Labrie, C. 2005. Is dehydroepiandrosterone a hormone? Journal of Endocrinology 187(2):169-196.

http://dx.doi.org/10.1677/joe.1.06264

Lacey, E.A., and Wieczorek, J.R. 2001. Territoriality and male reproductive success in Arctic ground squirrels. Behavioral Ecology 12(5):626-632. http://dx.doi.org/10.1093/beheco/12.5.626

LaMontagne, J.M., and Boutin, S. 2007. Local-scale synchrony and variability in mast seed production patterns of Picea glauca. Journal of Ecology 95(5):991 - 1000. http://dx.doi.org/10.1111/j.1365-2745.2007.01266.x

Le, P.P., Friedman, J.R., Schug, J., Brestelli, J.E., Parker, J.B., Bochkis, I.M., and Kaestner, K.H. 2005. Glucocorticoid receptor-dependent gene regulatory networks. PLoS Genetics 1(2):159- 170 . http://dx.doi.org/10.1371/journal.pgen.0010016

Lee, A.K., and Cockburn, A. 1985. Evolutionary ecology of marsupials. Cambridge: Cambridge University Press. http://dx.doi.org/10.1017/CBO9780511661693

Love, O.P., McGowan, P.O., and Sheriff, M.J. 2013. Maternal adversity and ecological stressors in natural populations: The role of stress axis programming in individuals, with implications for populations and communities. Functional Ecology 27(1):81-92. http://dx.doi.org/10.1111/j.1365-2435.2012.02040.x

Lupien, S.J., De Leon, M., De Santi, S., Convit, A., Tarshish, C., Thakur, M., McEwen, B.S., Hauger, R.L., and Meaney, M.J. 1998. Cortisol levels during human aging predict hippocampal atrophy and memory deficits. Nature Neuroscience 1:69-73. http://dx.doi.org/10.1038/271 
MacColl, A.D.C. 2011. The ecological causes of evolution. Trends in Ecology \& Evolution 26(10):514-522.

http://dx.doi.org/10.1016/j.tree.2011.06.009

Marshall, D.J., and Uller, T. 2007. When is a maternal effect adaptive? Oikos 116(12):1957-1963.

http://dx.doi.org/10.1111/j.2007.0030-1299.16203.x

McAdam, A.G., and Boutin, S. 2003. Variation in viability selection among cohorts of juvenile red squirrels (Tamiasciurus hudsonicus). Evolution 57(7):1689-1697.

McAdam, A.G., Boutin, S., Sykes, A.K., and Humphries, M.M. 2007. Life histories of female red squirrels and their contributions to population growth and lifetime fitness. Ecoscience 14(3):362-369.

http://dx.doi.org/10.2980/1195-6860(2007)14[362:LHOFRS]2. $0 . \mathrm{CO} ; 2$

McDonald, I.R., Lee, A.K., Bradley, A.J., and Than, K.A. 1981. Endocrine changes in dasyurid marsupials with differing mortality patterns. General and Comparative Endocrinology 44:292-301.

McDonald, I.R., Lee, A.K., Than, K.A., and Martin, R.W. 1986. Failure of glucocorticoid feedback in males of a population of small marsupials (Antechinus swainsonii) during the period of mating. Journal of Endocrinology 108:63-68.

http://dx.doi.org/10.1677/joe.0.1080063

McEwen, B.S., ed. 2001. Coping with the environment: Neural and endocrine mechanisms. Handbook of Physiology, Section 7: The Endocrine System, Vol. 4. New York: Oxford University Press.

McKinnon, L., Smith, P.A., Nol, E., Martin, J.L., Doyle, F.I., Abraham, K.F., Gilchrist, H.G., Morrison, R.I.G, and Bêty, J. 2010. Lower predation risk for migratory birds at high latitudes. Science 327(5963):326-327.

http://dx.doi.org/10.1126/science. 1183010

Meaney, M.J., Szyf, M., and Seckl, J.R. 2007. Epigenetic mechanisms of perinatal programming of hypothalamicpituitary-adrenal function and health. Trends in Molecular Medicine 13(7):269-277.

http://dx.doi.org/10.1016/j.molmed.2007.05.003

Nussey, D.H., Froy, H., Lemaitre, J.-F., Gaillard, J.-M., and Austad, S.N. 2013. Senescence in natural populations of animals: Widespread evidence and its implications for bio-gerontology. Ageing Research Reviews 12(1):214-225.

http://dx.doi.org/10.1016/j.arr.2012.07.004

Otte, C., Hart, S., Neylan, T.C., Marmar, C.R., Yaffe, K., and Mohr, D.C. 2005. A meta-analysis of cortisol response to challenge in human aging: Importance of gender. Psychoneuroendocrinology 30(1):80-91.

http://dx.doi.org/10.1016/j.psyneuen.2004.06.002

Ricklefs, R.E., and Wikelski, M. 2002. The physiology/lifehistory nexus. Trends in Ecology \& Evolution 17(10):462 - 468. http://dx.doi.org/10.1016/S0169-5347(02)02578-8

Romero, L.M. 2002. Seasonal changes in plasma glucocorticoid concentrations in free-living vertebrates. General and Comparative Endocrinology 128(1):1-24.

http://dx.doi.org/10.1016/S0016-6480(02)00064-3
Sapolsky, R.M., Krey, L.C., and McEwen, B.S. 1986. The neuroendocrinology of stress and aging: The glucocorticoid cascade hypothesis. Endocrine Reviews 7(3):284-301.

http://dx.doi.org/10.1210/edrv-7-3-284

Sapolsky, R.M., Romero, L.M., and Munck, A.U. 2000. How do glucocorticoids influence stress responses? Integrating permissive, suppressive, stimulatory, and preparative actions. Endocrine Reviews 21(1):55-89.

http://dx.doi.org/10.1210/er.21.1.55

Sheriff, M.J., and Love, O.P. 2013. Determining the adaptive potential of maternal stress. Ecology Letters 16(2):271 - 280 . http://dx.doi.org/10.1111/ele.12042

Sheriff, M.J., Krebs, C.J., and Boonstra, R. 2009. The sensitive hare: Sublethal effects of predator stress on reproduction in snowshoe hares. Journal of Animal Ecology 78(6):1249-1258. http://dx.doi.org/10.1111/j.1365-2656.2009.01552.x

. 2010. The ghosts of predators past: Population cycles and the role of maternal programming under fluctuating predation risk. Ecology 91(10):2983-2994.

http://dx.doi.org/10.1890/09-1108.1

Sheriff, M.J., Dantzer, B., Delehanty, B., Palme, R., and Boonstra, R. 2011a. Measuring stress in wildlife: Techniques for quantifying glucocorticoids. Oecologia 166(4):869-887.

http://dx.doi.org/10.1007/s00442-011-1943-y

Sheriff, M.J., Krebs, C.J., and Boonstra, R. 2011b. From process to pattern: How fluctuating predation risk impacts the stress axis of snowshoe hares during the 10-year cycle. Oecologia 166(3):593-605.

http://dx.doi.org/10.1007/s00442-011-1907-2

Sheriff, M.J., Wheeler, H., Donker, S.A., Krebs, C.J., Palme, R., Hik, D.S., and Boonstra, R. 2012. Mountain-top and valley-bottom experiences: The stress axis as an integrator of environmental variability in Arctic ground squirrel populations. Journal of Zoology 287(1):65 - 75.

http://dx.doi.org/10.1111/j.1469-7998.2011.00888.x

Sheriff, M.J., Fridinger, R.W., Tøien, Ø., Barnes, B.M., and Buck, C.L. 2013. Metabolic rate and prehibernation fattening in freeliving Arctic ground squirrels. Physiological and Biochemical Zoology 86(5):515-527. http://dx.doi.org/10.1086/673092

Sinclair, A.R.E., Krebs, C.J., and Smith, J.N.M. 1982. Diet quality and food limitation in herbivores: The case of the snowshoe hare. Canadian Journal of Zoology 60(5):889-897.

http://dx.doi.org/10.1139/z82-121

Sinclair, A.R.E., Chitty, D., Stefan, C.I., and Krebs, C.J. 2003. Mammal population cycles: Evidence for intrinsic differences during snowshoe hare cycles. Canadian Journal of Zoology 81(2):216-220.

http://dx.doi.org/10.1139/z03-006

Smith, J.N.M., Krebs, C.J., Sinclair, A.R.E., and Boonstra, R. 1988. Population biology of snowshoe hares. II. Interactions with winter food plants. Journal of Animal Ecology 57(1):269-286. http://dx.doi.org/10.2307/4778

Soma, K.K. 2006. Testosterone and aggression: Berthold, birds and beyond. Journal of Neuroendocrinology 18(7):543 - 551. http://dx.doi.org/10.1111/j.1365-2826.2006.01440.x 
Stefan, C.I., and Krebs, C.J. 2001. Reproductive changes in a cyclic population of snowshoe hares. Canadian Journal of Zoology 79(11):2101-2108.

Taymans, S.E., DeVries, A.C., DeVries, M.B., Nelson, R.J., Friedman, T.C., Castro, M., Detera-Wadleigh, S., Carter, C.S., and Chrousos, G.P. 1997. The hypothalamic-pituitary-adrenal axis of prairie voles (Microtus ochrogaster): Evidence for target tissue glucocorticoid resistance. General and Comparative Endocrinology 106(1):48-61.

http://dx.doi.org/10.1006/gcen.1996.6849

Williams, P.D., Day, T., Fletcher, Q., and Rowe, L. 2006. The shaping of senescence in the wild. Trends in Ecology \& Evolution 21(8):458-463.

http://dx.doi.org/10.1016/j.tree.2006.05.008

Wingfield, J.C., and Romero, L.M. 2001. Adrenocortical responses to stress and their modulation in free-living vertebrates. In: McEwen, B.S., ed. Coping with the environment: Neural and endocrine mechanisms. Handbook of Physiology, Section 7: The Endocrine System, Vol. 4. New York: Oxford University Press. $211-234$.

http://dx.doi.org/10.1002/cphy.cp070411
Wingfield, J.C., Lynn, S., and Soma, K.K. 2001. Avoiding the 'costs' of testosterone: Ecological bases of hormone-behavior interactions. Brain, Behavior and Evolution 57(5):239-251. http://dx.doi.org/10.1159/000047243

Wingfield, J.C., Kelley, J.P., Angelier, F., Chastel, O., Lei, F., Lynn, S.E., Miner, B., Davis, J.E., Li, D., and Wang, G. 2011. Organism-environment interactions in a changing world: A mechanistic approach. Journal of Ornithology 152 (Suppl. 1):S279-S288. http://dx.doi.org/10.1007/s10336-011-0668-3

Wolff, J.O. 1980. The role of habitat patchiness in the population dynamics of snowshoe hares. Ecological Monographs 50(1):111- 130 .

http://dx.doi.org/10.2307/2937249 